\section{The Corday-Morgan Memorial Fund Executive}

The Corday-Morgan Memorial Fund Executive is to sponsor two tours to Africa during the winter 1963-64. Prof. R. A. Raphael, Regius professor of chemistry in the University of Glasgow, is to visit Commonwealth territories in East Africa, including Uganda, Tanganyika and Kenya, and Prof. G. Kenner, Heath Harrison professor of chemistry in the University of Liverpool, will tour Commonwealth countries in West Africa. The CordayMorgan Memorial Fund Executive is derived from a bequest to the Chemical Society by Sir Gilbert Morgan, a past-president who died in February 1940. The Executive consists of the presidents and immediate pastpresidents of the Chemical Society, the Royal Institute of Chemistry, and the Society of Chemical Industry, and its purpose is to promote the unification of the chemical profession within the Commonwealth. It seeks to achieve this object by the appointment from time to time of a lecturer to visit some designated area of the Commonwealth overseas. In general, the visitor will tour the main academic and, where appropriate, industrial centres to give informal colloquia as well as formal lectures, and to discuss problems of mutual interest in the countries visited. Further information can be obtained from the Secretary, Corday-Morgan Memorial Fund Executive, c/o The Chemical Society, Burlington House, London, W.1.

\section{The Field Survey Association Annual Prize, 1963}

The Field Survey Association is offering a prize of $£ 50$ for the best article in English on any subject that falls within the Association's scope and is published during 1963 in a professional or trade journal of any organization which carries out any of the activities included within those of the Association. The prize is open to any person under the age of forty on the date of submission of his article for publication. It is not necessary to be a member of the Association to enter for the prize. The rules of the prize, the history and objects of the Association and the conditions of membership can be obtained from the honorary secretary of the Award Committee, Commander R. Bill, Vickers House, Millbank Tower, London, S.W.1.

\section{The Night Sky in October}

Fuli moon occurs on Oct. $3 \mathrm{~d}$ 04h $44 \mathrm{~m}$ U.T. and new moon on Oct. $17 \mathrm{~d} 12 \mathrm{~h} 43 \mathrm{~m}$. The following conjunctions with the Moon occur: Oct. 3d 12h, Jupiter $4^{\circ} \mathrm{N}$.; Oct. 20d 04h, Mars $4^{\circ}$ S.; Oct. 26d 20h, Saturn $2^{\circ}$ N.; Oct. $30 \mathrm{~d} 17 \mathrm{~h}$, Jupiter $4^{\circ} \mathrm{N}$. In addition to these conjunctions with the Moon, Venus is in conjunction with Spica on Oct. $6 \mathrm{~d}, 04 \mathrm{~h}$, Venus being $3^{\circ} \mathrm{N}$. Mercury is a morning star, rising about $1 \mathrm{~h} 40 \mathrm{~m}$ before the Sun on October 8 , and well placed for observation. Venus and Mars are too close to the Sun for observation. Jupiter is above the horizon most of the night, setting about two hours before sunrise on October 31. It is in Pisces, its stellar magnitude is -2.5 and its distance from the Earth on October 15 is 370 million miles. Opposition occurs on October 8. Saturn sets at $1 \mathrm{~h} 15 \mathrm{~m}, 0 \mathrm{~h} 15 \mathrm{~m}$ and $23 \mathrm{~h} 15 \mathrm{~m}$ at the beginning, middle and end of the month, respectively. It is in Capricornus, becoming stationary on October 21 and thereafter resuming its eastward motion among the stars. Its stellar magnitude is $+0 \cdot 8$, and its distance from the Earth on October 15 is 875 million miles. Occultations of stars brighter than magnitude 6 are as follows, obsorva. tions being made at Greenwich: Oct. 6d $23 \mathrm{~h} 12.4 \mathrm{~m}$, $\delta$ Tau. $(D)$; Oct. 7 d 0 h $14 \cdot 2 \mathrm{~m}, \delta$ Tau. $(R)$; Oct. 7 d 0 h $29.5 \mathrm{~m}, 64$ Tau. $(R)$; Oct. $7 \mathrm{~d}$ oh $35.9 \mathrm{~m}, 68$ Tau. $(D)$; Oct. 7d lh $35.0 \mathrm{~m}, 68$ Tau. $(R)$; Oct. $10 \mathrm{~d}$. 1h $44.4 \mathrm{~m}$, 63 Gem. $(R)$; Oct. $13 \mathrm{~d}$ 4h $22.4 \mathrm{~m}, 37$ Leo. $(R)$; Oct. $29 \mathrm{~d}$

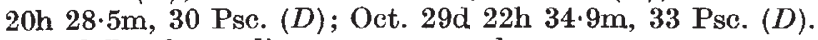
$D$ and $R$ refer to disappearance and reappearance, respectively. The Giacobinid meteors are active during October 9-10, but conditions for observation are rather unfavourable. The Orionid meteors are active during October 15-25, with a maximum on October 21 ; the radiant is near R.A. $6 \mathrm{~h} 24 \mathrm{~m}$, Dec. $+15^{\circ}$, and conditions for observation are very favourable.

\section{University News:}

Dr. M. J. T. Fitzgerald has been appointed reader in anatomy in University College, Cork (National University of Ireland). This is the first readership to be conferred since the foundation of the University.

\section{London}

The title of professor of computing science has been conferred on Dr. R. A. Buckingham, in respect of his post at the Computer Unit. The title of reader has been conferred on the following: Dr. W. C..Chaloner (botany), in respect of his post at University College; Mr. H. Billet (mechanical engineering), in respect of his post at University College; Dr. D. H. Martin (physics), in respect of his post at Queen Mary College; Dr. D. V. W. Parke (biochemistry), in respect of his post at St. Mary's Hospital Medical School.

Sussex

Dr. Z. BARBu, at present senior lecturer in the Depart. ment of Political and Social Theory at the University of Glasgow, has been appointed senior lecturer in social studies. Dr. R. R. Birss, at present lecturer in physics in the Department of Electrical Engineering, Imperial College of Science and Technology, London, has been appointed senior lecturer in experimental physics. Dr. S. Swierczkowski and Dr. G. L. Pratt have been appointed to lectureships in mathematics and chemistry, respectively.

\section{Announcements}

THE eighteenth Calorimetry Conference will be held at the Petroleum Research Center, Bartlesville, Oklahoma, during October 16-18. Further information can be obtained from Mr. John P. McCullough, Bartlesville Petroleum Research Center, P.O. Box 1321, Bartlesville, Oklahoma.

THE fourth international plasties industry fair will be held at Düsseldorf during October 12-20. The range of exhibits will cover main and ancillary materials, products, machinery and tools. Further information can be obtained from Nordwestdeutsche Ausstellungs- und Messe-Gesell. schaft m.b.H.-NOWEA, 4 Düsseldorf 10, Postfach 10203.

AN ordinary meeting of the Midlands Section of the Society for Analytical Chemistry will be held in Nottingham on October 15. A paper on "Sugars in Foodstuffssome Newer Methods" will be presented and discussed at the meeting. Further information can be obtained from the Society for Analytical Chemistry, 14 Belgrave Square, London, S.W.1.

THe laboratories of the Chalk Lime and Allied Indus. tries Research Association will be open to visitors from industry during October 9-10. The Association is concerned with research and with providing technical information for the lime, sand-lime bricks and the readymixed mortar industries. Further information can be obtained from the Secretary, Chalk Lime and Allied Industries Research Association, Church Street, Welwyn, Horts.

A covrse in "Ultrasonic Testing", arranged by the South Wales Branch of the Non-Destructive Testing Society of Great Britain, will be held in Swansea on five consecutive Tuesday evenings, commencing October 1. The course will include: basic principles; methods and application; examination of castings; examination of forgings and plant in service; modern developments. Further information cen be obtained from the Publicity Officer, the Non-Destructive Testing Society of Great Britain, 36 Willow Green, Ingatestone, Essex. 